REVIEW OF HISTORICAL SCIENCES 2017, VOL. XVI, NO. 3

http://dx.doi.org/10.18778/1644-857X.16.03.12

ILONA FLORCZAK

UNIVERSITY OF LODZ*

\title{
The letters from Zygmunt Celichowski to Kazimierz Bartoszewicz
}

he Archive of the Bartoszewicz Family which is kept in the
State Archive in Łódź, among the voluminous correspon-
dence of Kazimierz Bartoszewicz (1852-1930) contains the letters of Zygmunt Celichowski (1845-1923), a historian, publisher and librarian, associated with the Kornik Library since the late sixties of the $19^{\text {th }}$ century. In 1869, young Celichowski became the secretary of Jan Kanty Działyński ${ }^{1}$. A year later, the landlord of Kornik entrusted him with the management of the local library and, in 1876, of the Kórnik estate. In 1880, he obtained the same power of attorney from Władysław Zamoyski, Jan's nephew and the new owner of the properties. Celichowski remained connected with the Kornik Library until the end of his life. During numerous years of commitment, he contributed to the increase, organization and elaboration of the collection. Many of the collected materials

* The Faculty of Philosophy and History, The Institute of History, The Department of the History of Historiography and the Auxiliary Sciences of History / Wydział Filozoficzno-Historyczny, Instytut Historii, Katedra Historii Historiografii i Nauk Pomocniczych Historii, e-mail: ilona_florczak@wp.pl.

1 Jan Kanty Działyński (1829-1880), son of Adam Tytus and Gryzelda of the Zamoyski family; the last of the Działyński house to own the Kórnik estate; continued the work of his father, significantly increasing the collection of the library in Kornik. In the memory of the nation he prevails as a patron of culture. He died childless, transferring the estate and the Kornik Library on the son of his sister, Władysław Zamoyski. The life and work of Jan Działyński were portrayed by Andrzej Mężyński. See A. Mężyńs ki, Jan Działyński 1829-1880, Wrocław et al. 1987. 
appeared in print through his efforts ${ }^{2}$. Immersed in the scientific and publishing activity, Celichowski, as the director of one of the largest libraries in Poland, maintained a correspondence with various representatives of the Polish scientific community in the three partitions ${ }^{3}$. He was a member of the Poznan Society of Friends of Sciences and the Academy of Learning in Cracow (since 1903), as well as a correspondent member of the Historical and Literary Society in Paris ${ }^{4}$. Apart from being involved in the work for the Kornik Library and estate, Celichowski devoted himself to the social activity. He was a co-founder and a member of the People's Libraries Society, the Polish Bank of Commerce and the Society for the Promotion of Abstinence. At the end of his life, in recognition of his merit, the University of Poznan awarded him the title of an honorary professor of history ${ }^{5}$.

Kazimierz Bartoszewicz (1852-1930), a journalist, editor, publisher and social activist, born in Warsaw. He was the son of Julian (1821-1870), a well-known historian from the period between the November and January Uprisings. He spent most of his life in Cracow, where he moved in 1870 to study at the Jagiellonian University. From then on, he became permanently involved with the local literary and journalistic community, gradually becoming one of the most famous editors and writers in both, Galicia and the remaining partitions. His columns, essays and articles, aptly commenting on the affairs of the time, enjoyed popularity among readers, just as his historical papers. Bartoszewicz was not only famed for the sarcastic and witty writing style, but also for his exemplary use of the Polish language. He worked with various periodicals and journals in Galicia as well as in other partitions. Deeply engaged in the sphere of social activity, he also sought to consolidate the

2 The biographers of Zygmunt Celichowski emphasize that it was through the librarian's efforts that the publishing of, for example, the series "Acta Tomiciana" was continued. In 1996, vol. 24 of the "Pamiętniki Bilbioteki Kórnickiej" was released, presenting $Z$. Celichowski as a librarian, publisher and editor (managing the library of Jan Konstanty Żupański in Poznań, which was bought from the heirs).

${ }^{3}$ For example: Karol Estreicher or Alexander Kraushar. In 2011, the letters from the librarian of Kórnik to Alfons Parczewski were published. See E. Andrysiak, Listy Zygmunta Celichowskiego do Alfonsa Parczewskiego, "Biblioteka" 2011, No. 15 (24), pp. 269-270.

4 E. Musierowicz, Celichowski Zygmunt, [in:] Słownik pracowników ksiązki polskiej, Warszawa-Łódź 1972, pp. 105-106; "Rocznik Akademii Umiejętności w Krakowie", vol. 1904/1905, Kraków 1905, p. 39.

${ }^{5}$ E. Andrysiak, op. cit., p. 270. 
community of Polish writers. He was one of the active members of the Society of Art and Literature, an association of literary writers and artists, mostly from Cracow, or of the Literary Union (18911899) which was created later and of which he was a president in 1896-1899. It is worth mentioning that he initiated the creation of literary journals and undertook the work of the editor. The positions include: "Szkice Społeczne i Literackie" (1875-1876), "Przegląd Literacki i Artystyczny" (1882-1885) or "Przegląd Literacki" (1896-1899) ${ }^{6}$. Unfortunately, all of these titles, mostly for financial reasons, did not manage to stay on the market, despite having some of the most prominent writers of the period as contributors and being highly regarded by literary experts. The high artistic level of the periodicals was decisive about the audience too, the general public was not prepared for this type of content, while the men of letters, though interested, could not afford the subscription, primarily due to the uncertainty in the life of writers at the end of the $19^{\text {th }}$ and the beginning of the $20^{\text {th }}$ century. Moreover, having an image of publications which opposes to the views of conservatives from Cracow did not make it easier to attract a wider readership ${ }^{7}$.

It can be assumed that the correspondents knew each other in person. They might have met during the $2^{\text {nd }}$ convention of writers and journalists, held July 19-21, 1894, which was one of the events accompanying the Universal National Exhibition in Lviv. Both correspondents participated actively in the meeting. It was organized on a grand scale and was attended by the writers, journalists, scholars and men of letters from all the three partitions, as well as guests of other nationalities that were associated with the Galician literary community, such as Ivan Franko, Jaroslav Edvard Vrehlicky and Edvard Jelinek ${ }^{8}$.

The first of the letters kept in the Archive of the Bartoszewicz Family deals with scholarly matters, the librarian of Kórnik replies to the writer from Cracow who has requested to lend him materials

${ }^{6}$ I. Florczak, W obronie praw narodowych $-z$ działalności organizacyjnej i publicystycznej Kazimierza Bartoszewicza $w$ Krakowie w poczatkach XX wieku, [in:] Druga Rzeczpospolita i nie tylko. Ludzie, środowiska, idee. Profesorowi Pawłowi Samusiowi w 70 rocznice urodzin, ed. J. Pietrzak, Łódź 2016, p. 29.

7 More information: A. Zyga, Krakowskie czasopisma literackie drugiej połowy XIX wieku (1860-1895), Kraków-Wrocław 1983, p. 101 and the following.

8 Wystawa Krajowa, "Gazeta Lwowska", No. 166, July 22, 1894, pp. 4-5; Zjazd literatów i dziennikarzy polskich, "Myśl. Dwutygodnik literacko-społeczny”, July 19 (instead of 15), 1894. 
on Ignacy Działyński ${ }^{9}$. It seems probable that Bartoszewicz was looking for information in connection with the monograph about the Kościuszko Uprising which he was preparing. This publication is not merely a description of the events of the insurrection, but it also provides a broad historical background of the period ${ }^{10}$. In two subsequent letters, from July and August 1908, Zygmunt Celichowski addresses the issue of Polish-Ukrainian affairs. The subject of the mutual relations of the two nationalities, which coexisted in Galicia (especially in its eastern part), became particularly prominent on the political scene and in the social debate in April 1908, after the murder of the Viceroy of Galicia, Count Andrzej Potocki by the Ukrainian student, Myroslav Sichynsky ${ }^{11}$. As a result of the assassination (which was carried out for nationalistic reasons), the relations between representatives of both nations broke off and hostile actions of national organizations, both Polish and Ukrainian, intensified. Kazimierz Bartoszewicz made an attempt to portray these mutual relations in a newly created (June 1908) publication entitled "Straż Polska", a monthly which was a media outlet of the organization of the same name, established in Cracow for the sake of "defending the interests of the Polish nation". As a side note, it should be added that one of the reasons for its publication was the opposition to the Germanisation of Poles, the policy introduced by the authorities in the Prussian Partition ${ }^{12}$. Apart from the review of literature and of the published collection of documents, Bartoszewicz made a summary of the Polish-Ukrainian relations. He saw the solution to the nationalistic conflicts in granting greater national freedoms to the minorities of Galicia, along with an intro-

\footnotetext{
9 Ignacy Józef Franciszek Adam Działyński (1754-1797), son of Augustyn, the governor of Kalisz, and Anna Radomicka; cavalry captain, from 1790 deputy of the Great Diet, proponent of the Constitution of May 3, participant of the Polish-Russian War of 1792. In 1784, he married Szczęsna Woroniczówna, the castellan of Belz and the heiress of the lands in Volhynia in the vicinity of Zhytomyr, where he moved after the marriage. From his marriage with Woroniczówna, Ignacy Działyński had a son, Zygmunt, and two daughters. See S. Ki en iew ic z, Działyński Ignacy Józef Franciszek Adam (1754-1797), [in:] Polski słownik biograficzny, vol. VI, Kraków 1946, p. 80.

${ }^{10}$ K. Bartoszewicz, Dzieje insurekcji kościuszkowskiej, $1^{\text {st }}$ ed., Wiedeń 1909.

${ }^{11}$ On the murder of count Andrzej Potocki and its effects see C. Partacz, Od Badeniego do Potockiego. Stosunki polsko-ukrainskie w Galicji w latach 18881908, Toruń 1997, pp. 227-232.

12 More on the creation of the "Straż Polska": I. Florczak, op. cit., pp. 32-34.
} 
duction of a broad-scale educational campaign aimed at the common people whose consciousness should be shaped in the Polish spirit. A similar view was held by Zygmunt Celichowski, who lived in Kórnik, i.e. far from the place of conflicts. He was lively interested in education for the common people, also in Galicia. Let us recall that during the above-mentioned meeting of writers and journalists, Zygmunt Celichowski was the chair of the section 2 ("for the education of the common folk"), in which the need to create reading rooms for the people in the provinces or the distribution of works of the national literary canon were discussed. The mention of the Ukrainian issue in the Galician press prompted the librarian from Kornik to present his own view on the antagonisms between the two nations. His opinion and suggestions included in the letter were the thoughts of a man who is not directly involved in the conflict, looking at the affairs in Galicia from a considerable distance. Perhaps for this reason, Bartoszewicz came to the conclusion that the voice of the scholar and activist from Greater Poland was too important not to make it public. With the author's consent, excerpts from the letter dated July 11, 1908 were published in "Straż Polska" in the column The voice of members and readers ${ }^{13}$.

As mentioned above, the published letters are kept in the State Archive in Łódź, in the fonds of the Archive of the Bartoszewicz Family. They are just a fraction of the correspondence to Kazimierz Bartoszewicz, collected as a result of his professional activity. While preparing the letters, the orthography and punctuation were corrected in accordance with the current rules. In order to capture the style of the period, some of the words were left in unchanged grammatical form. Any additions and lacks in the text as well as illegible fragments are given in square brackets. The footnotes contain the necessary clarifications on persons and issues which require commentary.

$$
* * *
$$

13 Głosy członków i czytelników “Straży Polskiej”, "Straż Polska”, No. 4 of August 1908 , p. 5 . 
1.

\section{From Zygmunt Celichowski}

Kórnik, February 9, 1908.

\section{Gracious Sir,}

I would very much like to help you with the materials for the life story of Ignacy Działyński ${ }^{1}$, be it in my power. I shall mention that the old archive of the Działyński family is not to be found in Kornik. In the old days, Kórnik was not the seat of the Działyńskis, in the $18^{\text {th }}$ century, it changed hands through the wedlock and for two generations belonged to the Szołdrski family ${ }^{2}$.

In the early $19^{\text {th }}$ century, Xawery ${ }^{3}$ and Ignacy recovered it from the hand of the Szołdrski family. But Xawery was resided in Konarzewo, while Ignacy remained in the land partitioned by Moscow $^{4}$. It was Tytus Dz.[iałyński] ${ }^{5}$ who transferred his seat to Kórnik in 1820-1830, and settled here for good in 1840, after his return from Galicia. The Działyński family reclaimed Kórnik as arabiam desertam, empty, ruined and damp walls. What is to be found in Kórnik today was acquired by count Tytus and count Jan ${ }^{6}$.

[1] ${ }^{1}$ Ignacy Działyński (1754-1797) see footnote 9 of the introduction.

2 In 1790 , after the death of Teofila Działyńska $\left(1^{\text {st }}\right.$ married $n$. Szołdrska, $2^{\text {nd }}$ married n. Potulicka), the estate was inherited by her son, Feliks Szołdrski, and after he died childless it was overtaken by his cousin Wiktor Szołdrski. In 1801, as a result of winning a court case, the property returned to the Działyński family.

${ }^{3}$ Ksawery Szymon Tadeusz Działyński (1756-1819), son of Augustyn, the governor of Kalisz, and Anna Radomicka; Ignacy's younger brother; a deputy of the Great Diet from Wschowa Land, supporter of the Constitution of May 3 and its co-author; a senator and governor in the Duchy of Warsaw and the Kingdom of Poland; married to Justyna Dzieduszycka, with whom he had the son Tytus and daughters, Paulina Dzieduszycka and Klaudyna Potocka. He died in Konarzewo, which he governed.

${ }^{4}$ Ignacy Działyński died in Volhynia in 1797. Perhaps together with his younger brother, he sued the Szołdrskis over the properties of Kórnik, yet he died before the trial came to an end.

5 Adam Tytus Działyński (1796-1861), son of Ksawery and Justyna Dzieduszycka; a Polish aristocrat and politician, distinguished in the history of Poznań; creator of the Kórnik collection, patron of art, bibliophile and publisher of historical sources.

${ }^{6}$ See footnote 1 of the introduction. 
The son of Ignacy, Zygmunt ${ }^{7}$, and then his grandson Bronisław ${ }^{8}$, relocated to the south of Poland, to Ukraine. They hardly had any contact with Kórnik, hence, we are not in possession of any materials for Ignacy's biography, not even correspondence. As long as it is possible to work in unheated rooms of the library, I shall again scour the papers in which details about Ignacy can be expected - should I find anything, I will be pleased to provide it.

For me [illegible word] person of Ignacy, a big step and I would be content to contribute with at least one brick to the monument which you want to build for him in your work, Sir. His external appearance is winsome by itself. I have a photograph of his latest portrait. Should you wish to make a reproduction, I will gladly attend to it. I received a copy of it from Mr Kraushar', yet it was not too successful.

In the archives of the property, I have a considerable number of documents concerning Ignacy, as the two brothers were handling all the legal duties together for a time. I will see if any details regarding his death may be found in these documents. We also have a painting depicting an engagement between Ignacy and Woroniczówna. If you wish to include a reproduction of said painting in your work, Sir, I will order to have it photographed.

I do not know when you will need all the materials about Ignacy Działyński. I should avoid catching a cold, [and a bad cough?], which makes me cautious about spending time in unheated, not just cold, libraries, as usual, not such healthy places. Thus, if there is no rush, I would ask you, Sir, to postpone it for a while so that I could, at ease, browse through everything that might be of interest to you.

Please allow me to point your search into a direction which might lead to further information on the life of Ignacy. Bronisław Działyń-

${ }^{7}$ Zygmunt Działyński (1791-1850), the heir of Rzyszczewo and Trojanow in Ukraine, married to Aniela, and after her death with Emilia, the daughters of Stanisław Wodzicki, the president of the Senate of the Free City of Cracow.

8 Bronisław Działyński (1823-1860), son of Zygmunt and Aniela Wodzicka; the last owner of Rzyszczewo, Trojanów, Raba and Denisz in Ukraine. The last male descendant of the Ukrainian line of the Działyński family.

${ }^{9}$ Aleksander Kraushar (1843-1931), a historian, lawyer, publicist and poet from Warsaw. He had a lot of valuable contacts with representatives of the literary community in all the three partitions. At the turn of the $19^{\text {th }}$ and $20^{\text {th }}$ centuries, he led the salon of the city, where the cultural life of Warsaw was concentrated. He was a founding member of the Warsaw Scientific Society and a member of the History Enthusiasts' Society (and its head in 1912-1931). 
ski, the last man from the same branch of the family as Ignacy, was married to a woman whose maiden name was Komorowska. The marriage resulted in three daughters, one of whom was married to Stadnicki ${ }^{10}$. Perhaps any materials regarding Ignacy Dz.[iałyński] can be found in their house.

I regret I cannot be of more service to you as of now, Sir, but I do not abandon hope just yet. I shall search and there might be something to be found.

With sincere respect, Your obedient servant

Celichowski

Manuscript, ref. code 2946, pp. 7-10.

2.

From Zygmunt Celichowski

Kórnik, July 11, 1908.

Gracious Sir,

In the $3^{\text {rd }}$ issue of "Straż Polska", I have read the news about the intention to publish, in the Ruthenian language, small works and pamphlets for the Russified [!] Polish folk of the eastern Galicia.

I have wondered about this matter many a time and I have always considered it beneficial to propagate among the Ruthenian people such fair publications which, instead of racial or ethnic hatred, would spread the idea of amity and commonality [!] with the Polish nation. After all, it is not a novel idea as it must have been

${ }^{10}$ Daughter of Bronisław, Maria (approx. 1840-1894) married Count Władysław Stadnicki (1830-1894).

[2] 1 "Straż Polska", a monthly published in Cracow in the years 1908-1914, a media outlet of the organization of the same name, the purpose of which was broadly defined defense of the national interests. 
the motivation behind publishing, in 1879, Chociszewski's ${ }^{2}$ Istorija Polszy, Eytwy $i$ Rusy in the Ruthenian language, and additionally in two versions: in the Latin and Ruthenian alphabet. I am curious if the edition of which main warehouse was in the bookshop of Seyfarth and Czajkowski ${ }^{3}$, has been already sold out. A couple of years ago, I put forward the idea of re-publishing it - I was told it would be a futile effort as no Ruthenian would buy such a book nowadays. If not bought, it should be distributed free of charge. In my opinion, all the works of our literature should have their Ruthenian translations. It might serve as the most effective propaganda of amity between us and the Ruthenians. Another book which I believe should be translated into the Ruthenian language is the novel by Je $\dot{z}^{4}$ entitled Hryhor serdeczny ${ }^{5}$. Maybe it would be possible [to distribute?] a certain number of copies of this novel among the Ruthenians who speak Polish.

And what about launching the propaganda to introduce the Latin alphabet among the Ruthenians? I suppose this issue could be also raised at the Slavic Congress in Prague ${ }^{6}$.

With the deepest respect and kind regards, Your obedient servant

Celichowski

Manuscript, ref. code 2946, pp. 5-6.

\footnotetext{
2 Józef Chociszewski (1837-1914), born in the Prussian partition, Polish populist and writer, editor and publisher, author of numerous works in the field of literature and history for the common people.

${ }^{3}$ Gustaw Seyfarth (1840?-1923) and Damian Czajkowski ran a bookshop in Lviv since 1868. Apart from publishing and selling very differently themed works, they had a bookshop and were renting books as well as musical notes and instruments.

${ }^{4}$ Teodor Tomasz Jeż [Zygmunt Miłkowski] (1824-1915), a novelist, democracy and independence activist, publicist. He created works based on Slavic and South Slavic themes, in which he was weaving carefully concealed Polish matters.

${ }^{5}$ Hryhor sedeczny, a novel published in 1873.

6 The Neo-Slavic Congress in Prague, a congress of representatives of the Slavic nations, which was held July $12-18,1908$. The aim was to bring the Slavic nations together and to create a common front in the fight against Germanization.
} 


\section{3. \\ From Zygmunt Celichowski}

Kórnik, August 17, 1908.

\section{My very Gracious Lord!}

I do not recall what I wrote to you about the publication of Ruthenian books. I do not think there was anything that I could not publicly admit. Hence, I wouldn't have any objections to sign my name under the letter. Yet, the question is whether the form of the letter was apt for publication.

We, the people of Greater Poland, know the Ruthanian matter only from afar since we do not come into regular contact with it. And therefore, the real possibility of causing harm while acting in the best of intentions is worrisome. While you, Sirs, deal with the Ruthenians and the Ruthenian matter directly, and you can assess in the best of ways what has to be done. And our duty is to support you and follow you in any direction you decide to take.

If you, however, consider that publishing the letter, whether anonymously or signed with the name, could be of any use, even if to simply encourage the debate, then the consent is given.

Some time ago, in our papers appeared news about a truly conciliatory speech by Mr Sabat, the principal of a gymnasium ${ }^{1}$. I could not help myself and dropped him a line to thank him for his speech and to pass the idea of a publication whose purpose would be to bring the two differing brothers together. You, Sirs, are well acquainted with the prin.[cipal] Sabat, and so I would like to draw your attention to his person.

Is Kałużniacki ${ }^{2}$ still a professor at the University of Chernivtsi?

I once corresponded with him and I had the feeling that I managed to break down his aversion and prejudice which he held towards us.

[3] ${ }^{1}$ Mikolaj Sabat, a director of Imperial-Royal gymnasium in Stanisławowo with the Ruthenian as the language of instructions ("Szematyzm" 1908).

${ }^{2}$ Emil Kałużniacki (1845-1914), a Slavic philologist, employed at the University of Chernivtsi in 1875 . In the years $1889-1890$, a rector of the said university. 
I also met Franko ${ }^{3}$, who still worked with us in 1894 during the Lviv exhibition at the literary convention ${ }^{4}$, where I presided in the section of the education of the common folk. Tempora mutantur $^{5}$, and people change too, but they change more than once. What could make Franko take up such a hateful stance towards us?, Mostly personal reasons are involved. Quite often we forget our proverb: ["] hospitality wins people over ["].

Your letter, Sir, made an old, familiar thought pass through my mind again, to undertake an initiative to create, or rather recreate, the Polish-Ruthenian union. Wouldn't it be possible and advisable to form an association which would serve such a purpose? For a start, let us gather a Group of twenty Poles and as much Ruthenians, which would steadily grow larger, and whose list of duties would be: to ease the strife and the union!

I promised to send you, Sir, a photograph of Ignacy Działyński's portrait, which is kept in our palace in Poznań. Not a successful photograph, as the painting is old and rather unclean. We have another painting in Kórnik, which is clearer, but I believe it is a copy from the one in Poznan. Thus, I ordered to take a photograph of the latter, as it is more authentic.

With sincere and profound respect,
Your obedient servant

Celichowski

${ }^{3}$ Ivan Franko (1856-1916), Ukrainian poet, writer, Slavist, social and political activist, expert in Polish literature, editor of journals, co-creator of Galician progressive movements. He was active in the Polish and the Ukrainian community. He cooperated with various representatives of the Polish literary community. The author of the letter accurately assessed the motives that led the Ukrainian activist and influenced his change of attitude towards the Polish people, personal failures, i.e. the defeat in the elections to the Galicia Diet, and the refusal to appoint him to the chair of literature and the Ukrainian language at the University of Lviv, had undoubtedly an influence on Franko's bitterness and his criticism of Adam Mickiewicz's works in an article published in 1897, which, in turn, outraged the Poles.

${ }^{4}$ See footnote 8 of the introduction. Ivan Franko gave a lecture on correlations between the Polish and the Ukrainian literature, expressing the need for the Poles to familiarize themselves with the works of Ukrainian writers during, for example, organized lectures and events popularizing the publications.

${ }_{5}$ Tempora mutantur (Latin), times change. 
PS Now I wonder whether my letter contains excursions against the Prussian government. It would have to be left out, not for me, but for the sake of Kórnik.

Manuscript, ref. code 2946, pp. 1-3.

\section{Bibliography}

\section{HANDWRITING SOURCES}

The State Archive in Łódź

(Archiwum Państwowe w Łodzi)

The Archive of the Bartoszewicz Family, ref code. 2946.

(Archiwum rodziny Bartoszewiczów)

\section{Printed sources}

Andrysiak E., Listy Zygmunta Celichowskiego do Alfonsa Parczewskiego, "Biblioteka” 2011, No. 15 (24), pp. 269-279.

\section{Press}

“Rocznik Akademii Umiejętności w Krakowie”, vol. 1904/1905, Kraków 1905.

"Straż Polska", No. 4 of August 1908.

Wystawa Krajowa, "Gazeta Lwowska”, No. 166, July 22, 1894.

Zjazd literatów i dziennikarzy polskich, "Myśl. Dwutygodnik literacko-społeczny", July 19 (instead of 15), 1894.

\section{STudies}

Bartoszewicz K., Dzieje insurekcji kościuszkowskiej, Wiedeń 1909.

Florczak I., W obronie praw narodowych $-z$ działalności organizacyjnej i publicystycznej Kazimierza Bartoszewicza w Krakowie w poczatkach XX wieku, [in:] Druga Rzeczpospolita i nie tylko. Ludzie, środowiska, idee. Profesorowi Pawłowi Samusiowi w 70 rocznicę urodzin, ed. J. Pietrzak, Łódź 2016, pp. 25-38.

Kieniewicz S., Działyński Ignacy Józef Franciszek Adam (1754-1797), [in:] Polski słownik biograficzny, Kraków 1946, vol. VI, p. 80.

Mężyński A., Jan Działyński 1829-1880, Wrocław et al. 1987.

Musierowicz E., Celichowski Zygmunt, [in:] Słownik pracowników książki polskiej, Warszawa-Łódź 1972, pp. 105-106.

Partacz C., Od Badeniego do Potockiego. Stosunki polsko-ukrainskie w Galicji w latach 1888-1908, Torun 1997.

Zyga A., Krakowskie czasopisma literackie drugiej połowy XIX wieku (1860-1895), Kraków-Wrocław 1983. 